\title{
Discovery of the subfamily Microtypinae (Hymenoptera: Braconidae) in Egypt, with the description of a new species
}

\section{Yusuf A. Edmardsah, Neveen S. Gadallah \& Kees van Achterberg}

To cite this article: Yusuf A. Edmardsah, Neveen S. Gadallah \& Kees van Achterberg (2017) Discovery of the subfamily Microtypinae (Hymenoptera: Braconidae) in Egypt, with the description of a new species, Zoology in the Middle East, 63:3, 239-249, DOI: 10.1080/09397140.2017.1331585

To link to this article: https://doi.org/10.1080/09397140.2017.1331585

\section{册 Published online: 25 May 2017.}

\section{Submit your article to this journal $\square$}

Џ Article views: 37

Q View related articles $๘$

View Crossmark data ¿ 


\title{
Discovery of the subfamily Microtypinae (Hymenoptera: Braconidae) in Egypt, with the description of a new species
}

\author{
Yusuf A. Edmardsah ${ }^{\mathrm{a}}$, Neveen S. Gadallah ${ }^{\mathrm{a},{ }^{*}}$ and Kees van Achterberg ${ }^{\mathrm{b}}$ \\ ${ }^{a}$ Entomology Department, Faculty of Science, Cairo University, Giza, Egypt; ${ }^{b}$ Department of \\ Terrestrial Zoology, Naturalis Biodiversity Center, Leiden, The Netherlands
}

(Received 25 April 2017; accepted 9 May 2017; first published online 25 May 2017)

\begin{abstract}
The subfamily Microtypinae Szépligeti, 1908 (Hymenoptera: Braconidae) is recorded for the first time for Egypt. The present study is based on specimens collected from Gebel Elba, Wadi Allaqi, St. Catherine, and Fayoum, as well as specimens deposited in various entomological collections in Egypt. Four species belonging to the genus $\mathrm{Mi}$ crotypus Ratzeburg, 1848 (M. algiricus Szépligeti, 1908; M. desertorum Shestakov, 1932; M. vanharteni van Achterberg, 2010 and M. aegypticus sp. n.) are reported for the first time from Egypt.
\end{abstract}

http://www.zoobank.org/urn:lsid:zoobank.org:pub:022282A1-183F-4E0C-9F88A53C42735532

Keywords: Microtypus; new records; new species; Gebel Elba; Wadi Allaqi; St. Catherine; Egypt

\section{Introduction}

Microtypinae Szépligeti, 1908 is a small subfamily of Braconidae (Hymenoptera) with a nearly worldwide distribution, but unknown from Australia ( $\mathrm{Yu}$, van Achterberg \& Horstmann, 2012). Currently, 22 species are known from three genera (Microtypus Ratzeburg, 1848; Neomicrotypus van Achterberg, 1992 and Plesiotypus van Achterberg, 1992) (van Achterberg, 1992; Yu et al., 2012; Sabahatullah, Inayatullah \& Tahira, 2015), most of them (16 species) belong the genus Microtypus Ratzeburg, 1848, of which only six species are extant; the remainder concerns fossil species (Yu et al., 2012).

In 1984, van Achterberg included Microtypini in the subfamily Homolobinae van Achterberg, 1979. The Microtypinae resemble both Homolobinae and the Orgilinae to some degree (van Achterberg, 1992). They resemble Homolobinae in having the metasomal T1 broad at base, and both of them are endoparasitic in lepidopterous larvae (van Achterberg, 1992). On the other hand, they are closely related to Orgilinae (especially tribe Mimagathidini) in having a similar wing venation, and both of them contain parasites of concealed lepidopterous larvae (van Achterberg, 1992). Biology and larval morphology of both Microtypinae and Orgilinae indicate a sister relationship, Orgilinae (Homolobinae + Microtypinae) which is proposed by some authors (e.g. Čapek, 1970; van Achterberg, 1984, 1992). This hypothesis was strongly supported by a phylogenetic study using molecular analysis (Sharanowski, Dowling \& Sharkey, 2011).

Microtypinae are mainly diagnosed by the following combination of characters: the presence of a small triangular or trapezoidal forewing SMC2; first metasomal tergite (T1) is broad basally, with very weak or absent dorsal carinae; absence of apical hind

\footnotetext{
*Corresponding author. Email: n_gadallah@hotmail.com
} 
tibial pegs, or at most the presence of spiny subapical bristles; scutellum distinctly depressed medio-posteriorly; the triangular or slit-like pronope (van Achterberg, 1987, 1992; Wharton, 1997).

Little is known about the biology of most species, but two Microtypus species (M. trigonus (Nees) and M. wesmaelii Ratzeburg) are considered to be koinobiont endoparasitoids of concealed microlepidopterous larvae of the families Gelechiidae, Pyralidae, Tortricidae and Yponomeutidae (van Achterberg, 1992; Čapek \& van Achterberg, 1992; van Achterberg, 1997).

Four species of Microtypus are reported here from Egypt for the first time.

\section{Study Area}

The present study is based on specimens collected from Fayoum, Gebel Elba and Bahariya oasis as well as those deposited on the different Egyptian insect collections.

Gebel Elba $\left(22^{\circ} 00^{\circ}-23^{\circ} 02^{\circ} \mathrm{N}, 36^{\circ} 00^{\circ}-36^{\circ} 55^{\prime} \mathrm{E}\right)$ is situated at the south corner of the Arabian desert of Egypt. It covers approximately $10,000 \mathrm{~km}^{2}$ and comprises eleven main wadis (AlGohary, 2008). The region is a transitional zone between the Palaearctic and Afrotropical ecozones (Benson, Clancey, Frey, Newman, Prigogine, \& Snow, 1979). The phytogeographical affinities are distinctly those of the Afrotropical region (Fahmy, 1936). The richness of vegetation of Gebel Elba is notable as compared with other parts of the Eastern Desert (El-Hadidi, 2000), as it comprises more than 458 plant species (Zahran \& Willis, 1992) of which the proportion of tree and shrub species is much higher than any other region in Egypt (Al-Gohary, 2008). Some of the Sahelian woody trees are restricted to Gebel Elba and unknown from any other part of Egypt (Boulos, 1999-2005). Many Afrotropical elements have their northern limits at Gebel Elba; it is dominated by the dense cover of acacias and other shrubs that represent the only natural woodland in Egypt (Al-Gohary, 2008).

Wadi Allaqi $\left(22^{\circ} 53^{\prime} \mathrm{N}, 32^{\circ} 54^{\prime} \mathrm{E}\right.$ ] a wadi situated in southern Egypt. It begins in Sudan below the Halayeb triangle and ends south of Aswan on the eastern shore of Lake Nasser (UNESCO: Biosphere Reserve Information). It covers $30,000 \mathrm{~km}^{2}$ and consists of protected desert area. The Wadi is a large dry river, with more than 90 annual and perennial plant species (Springuel \& Sheded, 1997). Plants from four floristic regions are present: Mediterranean species extending further into the Euro-Siberian region are together with Irano-Turanian; Saharo-Arabian and Sudanian species that extends further into tropical Africa (Springuel \& Sheded, 1997). It is dominated by four plant species groups: Tamarix nilotica species group, Cullen plicatum species group, Acacia ehrenbergiana species group and A. tortilis species group (Springuel \& Sheded, 1997).

\section{Terminology and Identification}

Sampling was done by means of light trapping and yellow pans. Photos were taken by a Canon (G12) camera attached to Optech trinocular zoom stereomicroscope (LFZT). Measurements of the different parts were made with the help of an ocular micrometer.

Morphological terms, including wing venation, are based on van Achterberg (1992) and Čapek and van Achterberg (1992). Body sculpture terminology follows Harris (1979). Identification to the subfamily based on van Achterberg (1993), to the genus follows van Achterberg (1992) and the species level on Čapek and van Achterberg (1992) and van Achterberg (2010). Distribution of the Microtypus species is based mainly on Yu et al. (2012).

The type specimens of the new species are deposited in the Plant Protection Institute collection, Ministry of Agriculture, Giza, Egypt (PPDD).

\section{Abbreviations and Depositories}

1-CU1: first sector of Cubitus; 3-CU1: third sector of Cubitus; CU1b: the second divergent vein from 3-CU1; cu-a: transverse cubito-anal vein; F: antennal flagellomere; 1-M: first sector of medial vein; $\mathrm{M}+\mathrm{CU}$ : Medial vein overlayed with Cubitus; OD: diameter of posterior ocellus; 


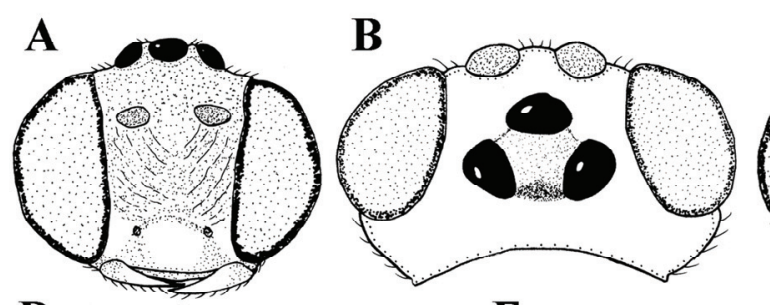

D

E

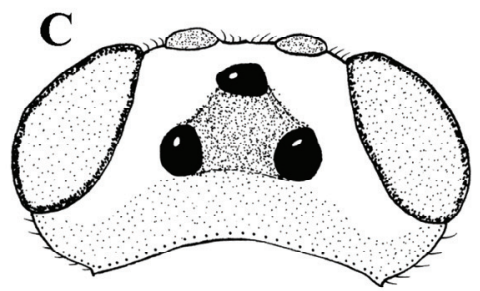

F
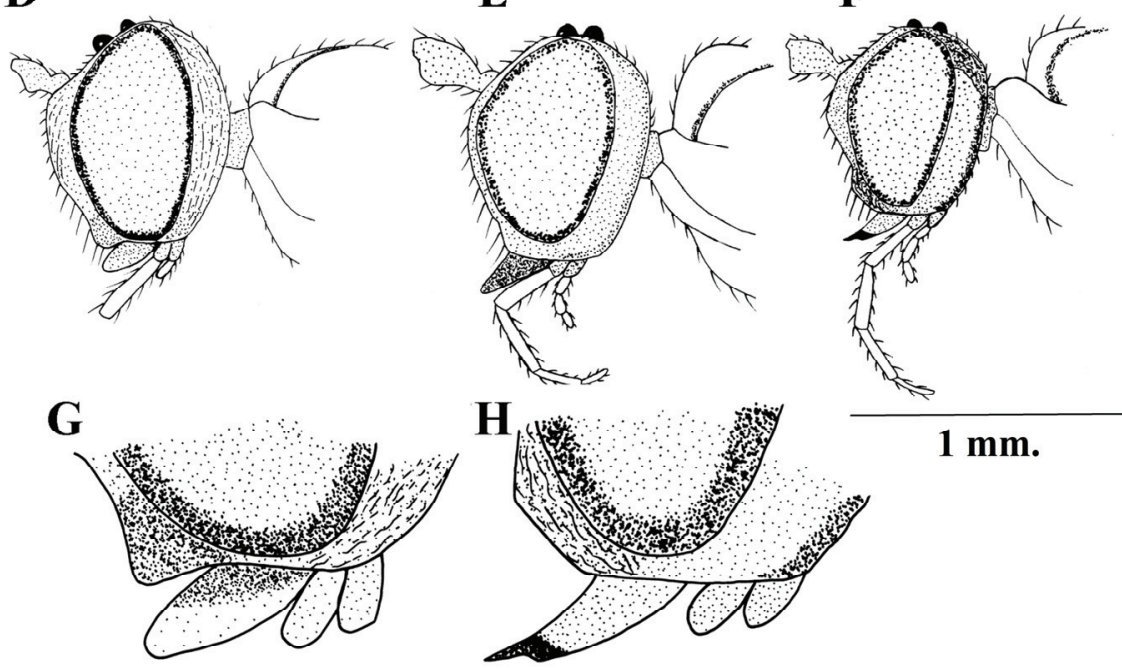

$1 \mathrm{~mm}$.

Figure 1. (A) Head, M. algiricus Szépligeti, frontal aspect; (B) and (C) Head, dorsal aspect, (B) M. desertorum Shestakov; (C) M. vanharteni van Achterberg; D-F, Head, lateral aspect. (D) Microtypus algiricus Szépligeti; (E) M. vanharteni van Achterberg; (F) M. desertorum Shestakov; (G) and (H) malar space , (G) M. algiricus Szépligeti; (H) M. desertorum Shestakov (all 1× scale line; $\mathrm{G}, \mathrm{H} 2.4 \times$ scale line).

OOL: ocular-ocellar line; POL: posterior ocellar line; $r$ : transverse radial vein; $r-m$ : transverse radio-medial vein; SMC2: second submarginal cell of fore wing; 1-SR: first sector of radial vein; 1-SR+ M: first sector of section radial vein overlayed with Medial vein; 2-SR: second sector of sectio radii; SR1: section-radial vein; T: metasomal tergite.

ASUA = Ain Shams University collection, Entomology Department, Faculty of Science, Cairo, Egypt. $-\mathbf{E F C}=$ Efflatoun Bey collection, Entomology Department, Faculty of Science, Giza, Egypt. - PPDD = Plant Protection Institute collection, Ministry of Agriculture, Giza, Egypt.

\section{Taxonomy}

\section{Microtypus Ratzeburg, 1848}

Microtypus Ratzeburg, 1848: 47. Type species: Microtypus wesmaelii Ratzeburg, 1848, by monotypy.

Similearinus Glowacki \& Kapińsky, 1967: 89, 95. Type species: Similearinus ilinskyi Glowacki \& Kapińsky, 1967, by monotypy. 


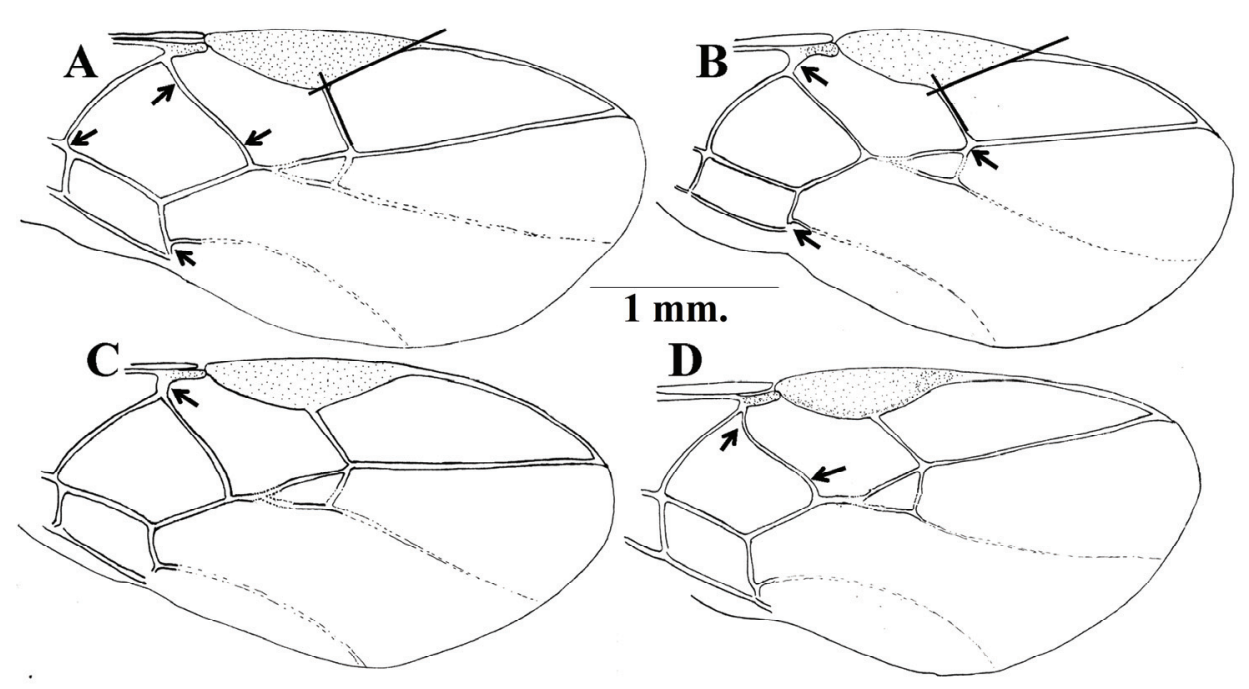

Figure 2. A-D, Apical half of fore wing. (A) Microtypus wesmaelii Ratzeburg (after Čapek and van Achterberg, 1992; Farahani, 2014); (B) M. desertorum Shestakov; (C) M. algiricus Szépligeti; (D) M. vanharteni van Achterberg. (1× scale line).

Microtypus aegypticus sp. n. (Figure 5A, 5B, 5D-J)

Material: Holotype, $q$, Egypt: Gebel Elba (Mersa Gereed) (22 $\left.41^{\prime} 38^{\prime} ’ \mathrm{~N} ; 36^{\circ} 42^{\prime} 11^{\prime \prime} \mathrm{E}\right)$, 4.i.1981 (leg. M. G. H), light trap [PPDD]. - Paratype, 1ㅇ, Egypt: Gebel Elba (W. Lahami) (2413'00'’N; 35²5’01'’E), 25.i.1982 [ASUA].

Description. Female, holotype. Body length $6.2 \mathrm{~mm}$, fore wing length $5.8 \mathrm{~mm}$. Head. Antenna 39-segmented (only left antenna complete), its length 0.9 times as long as fore wing, covered with dense and tiny white setae especially on ventral side of scapus and pedicellus, F1 about 1.1 times as long as F2, length of F1, F2 and penultimate segment 2.3 times, 2.2 times and 1.8 times as long as wide, respectively, terminal segment with fine and relatively long spine (Figure 5B, as compared with normal spine of $M$. desertorum (Figure 5C)); maxillary palp 0.8 times as long as height of head (Figure 5D); occipital carina complete dorsally, as ventrally but wider; length of eye in dorsal view 2.2 times temple (Figure 5E); temples strongly narrowed behind eyes (Figure 5E); ocelli shiny and normally protuberant, anterior ocellus is at far distance from posterior ocelli, OOL: OD: POL = 9:13:11 (Figure 5E); frons flat (except for very weak ridge medially), densely covered with short and erect white setae that is longer than those of antennal base, finely punctate, smoother near eye orbit, the inter-antennal area shallowly granulated; vertex shiny and largely smooth, with very fine oblique striae, setose, and its setae similar to those of frons; face convex, sparsely punctate; clypeus weakly convex and sparsely punctate and its ventral margin thin, slightly curved and near lower level of eyes; anterior tentorial pits large; occipital flange indistinct; length of malar space about 0.6 times basal width of mandible (Figure $5 \mathrm{~F}$ ); malar suture represented by very narrow line and more distinct anteriorly. - Mesosoma. Length of mesosoma 1.5 times its height; shiny, pronotum largely smooth, with fine strigulation ventro-laterally; notauli complete, with fine but obvious granulation; mesoscutum convex, largely smooth, rugulose postero-laterally; sides of scutellum covered with fine setae laterally, and longitudinally 


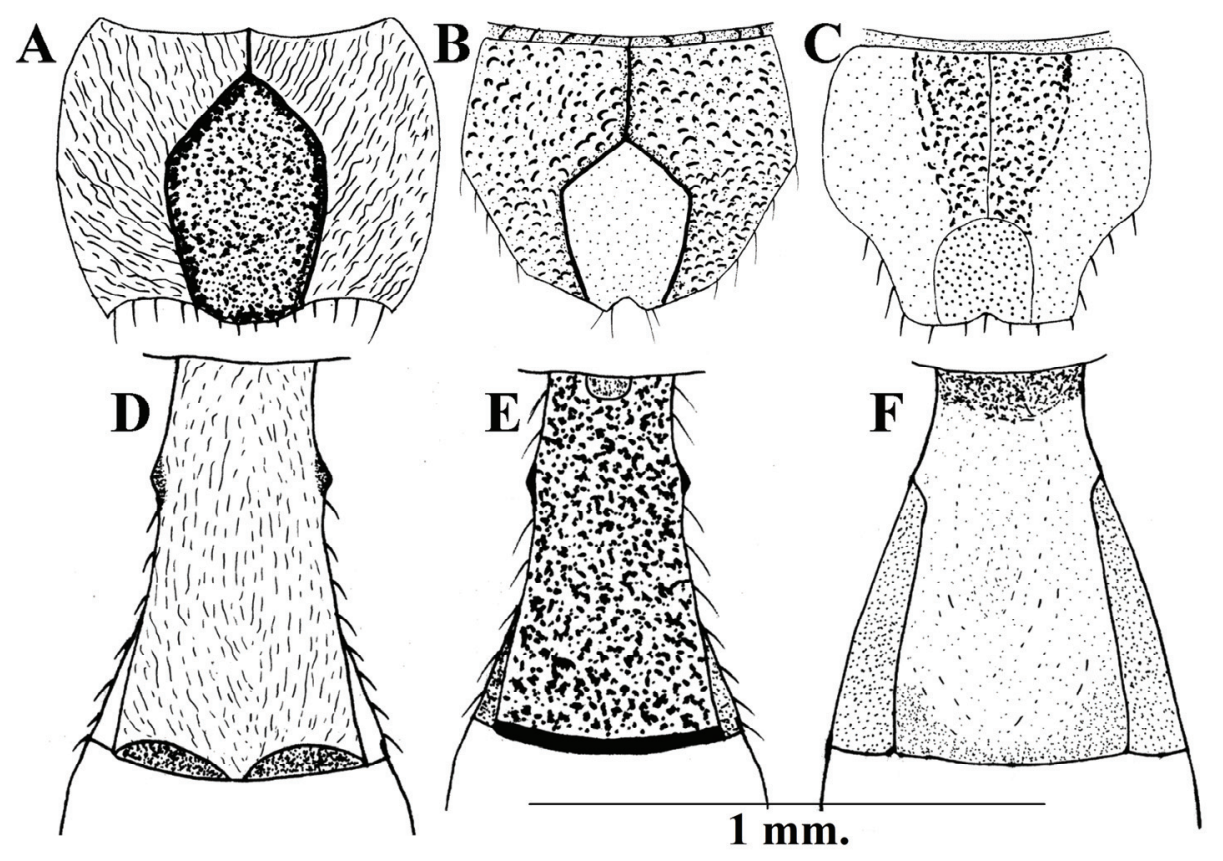

Figure 3. A-C, Propodeum. (A) Microtypus algiricus Szépligeti; (B) M. desertorum Shestakov; (C) M. vanharteni van Achterberg; D - F, first metasomal tergite. (D) M. algiricus Szépligeti; (E) M. desertorum Shestakov; (F) M. vanharteni van Achterberg (all $1 \times$ scale line; D-F $1.2 \times$ scale line).

finely strigose (especially laterally distinct); scutellar sulcus completely smooth; metanotum obviously depressed, distinctly and spaced scrobiculate; surface of propodeum antero-laterally and posteriorly moderately rugose to smooth, but coarser along well-defined rugulose, areola or lateral carina absent (Figure 5G). Wings. Fore wing (Figure 5A): 1-SR short and distinct, very small oblong parastigma subtriangular, narrowly separated from pterostigma, r: SR1: 2-SR: $r-m=15: 52: 12: 10$; SMC2 sessile; 1$\mathrm{SR}+\mathrm{M}$ sinuate, showing asymmetrical sinuation where the vein curved ventrally more strongly than dorsally; $\mathrm{r}$ long, oblique, inclivous, 1.6 times as long as width of pterostigma and from middle of pterostigma; cu-a subinterstitial, inclivous and long; 3CU1 inclivous. Hind wing: cu-a slightly reclivous; marginal cell slightly widened apically; M+CU: 1-M: 1r-m = 44: 24: 45; subbasal cell sparsely setose. Legs. setose, especially tarsi, hind femora and tibia; hind coxa superficially punctulate and dorsally with a few oblique rugae; tarsal claws slender, with apex curved; length of hind femur, tibia and basitarsus (Figure 5I) 7.2, 14.1 and 8.9 times their maximum width respectively; length of both hind tibial spurs 0.45 times as long as hind basitarsus (Figure 5I), claw of hind tarsus, densely setose, narrowly attached, semi-fusiform and with fine terminal tooth (Figure 5J). - Metasoma. T1 1.7 times its width posteriorly, distinctly narrowed behind spiracles, apical two thirds with longitudinal and irregular striae, slightly smoother laterally, its apical third largely smooth (Figure 5H); other tergites with sculpturing finer than that of first one, latero-tergites with fine, longitudinal striae; generally sculpture becoming finer as we directed posteriorly; length of ovipositor sheath 0.34 times as long as fore wing. - Colouration. Body generally dark brown to blackish; 


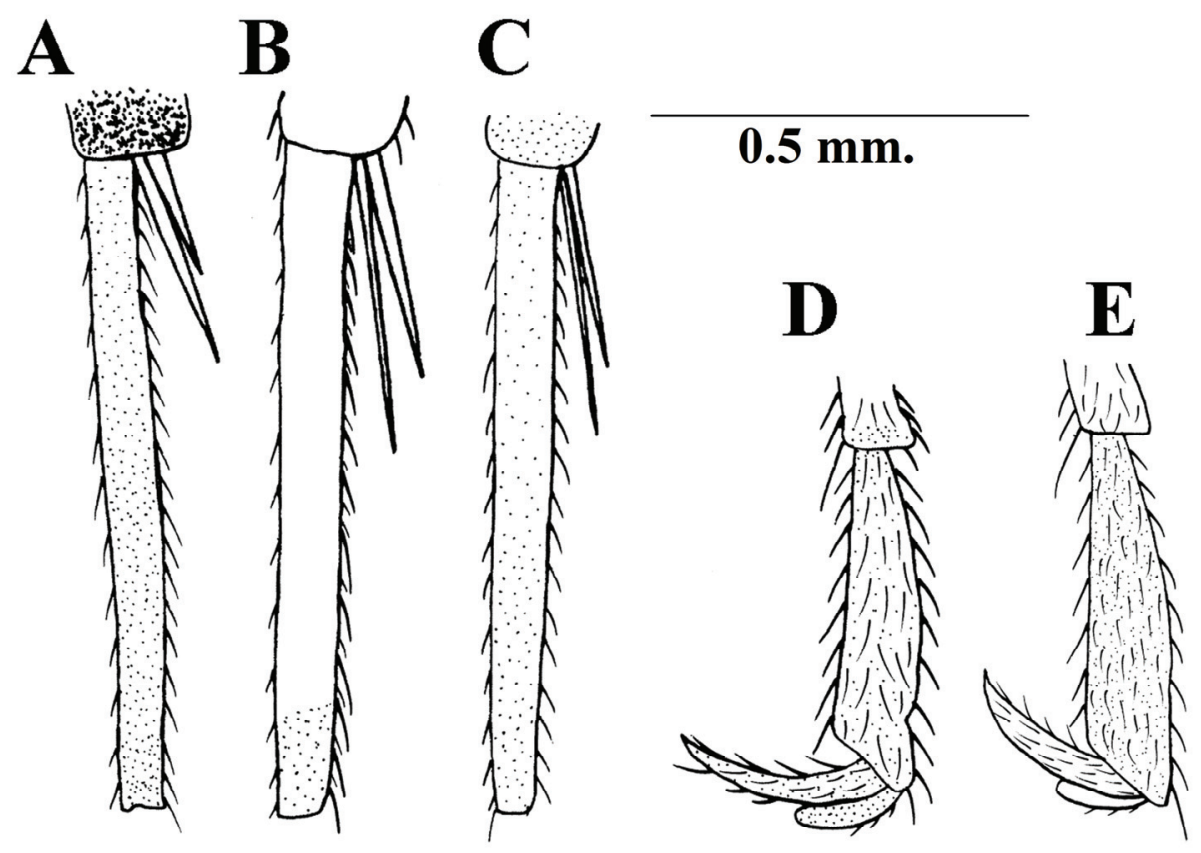

Figure 4. A-C, Hind basitarsus. (A) Microtypus algiricus Szépligeti; (B) M. desertorum Shestakov; (C) M. vanharteni van Achterberg; D and E, hind claw of female. (D) M. algiricus Szépligeti; (E) M. desertorum Shestakov (all $1 \times$ scale line; D, E $2.6 \times$ scale line).

stemmaticum black; antenna entirely brownish, but its apical half slightly darker; frons medially with dark hue; tips of mandible black; pterostigma distinctly yellowish, except for very thin brownish line and anterior diffused spot, all veins brownish, $\mathrm{C}+\mathrm{SC}+\mathrm{R}$ darker brown; wing membrane hyaline; legs yellowish, with coxae, mid and hind femora darker ventrally and posteriorly; middle lobe of mesoscutum (between notauli) somewhat darker than rest of mesosoma; second and third latero-tergites blackish; ovipositor sheath with apical third entirely black.

Male: Unknown.

Variation: Female paratype is very similar to holotype but metasoma completely darkened, sculpture more pronounced, ocelli somewhat closer to each other, and antenna with 40 segments.

Remarks: The new species runs with the key by van Achterberg (2010) to M. petiolatus van Achterberg, 1992. It differs by having the frons brown medially (brownish yellow in petiolatus), the second submarginal cell of fore wing sessile (petiolate), larger ocelli (smaller) and the propodeum with a median carina (absent). The new species is also similar to M. algiricus Szépligeti but differs by having the antenna with 39-40 segments (49-52 segments in M. algiricus), the scapus and pedicellus unicoloured (contrasting the colour of flagellomeres) and the malar space 0.6 times basal width of mandible (0.1 times).

Distribution: Only known from Gebel Elba, Egypt.

Host records: Lobesia spp. (Tortricidae) (according to the label of the holotype specimen). 

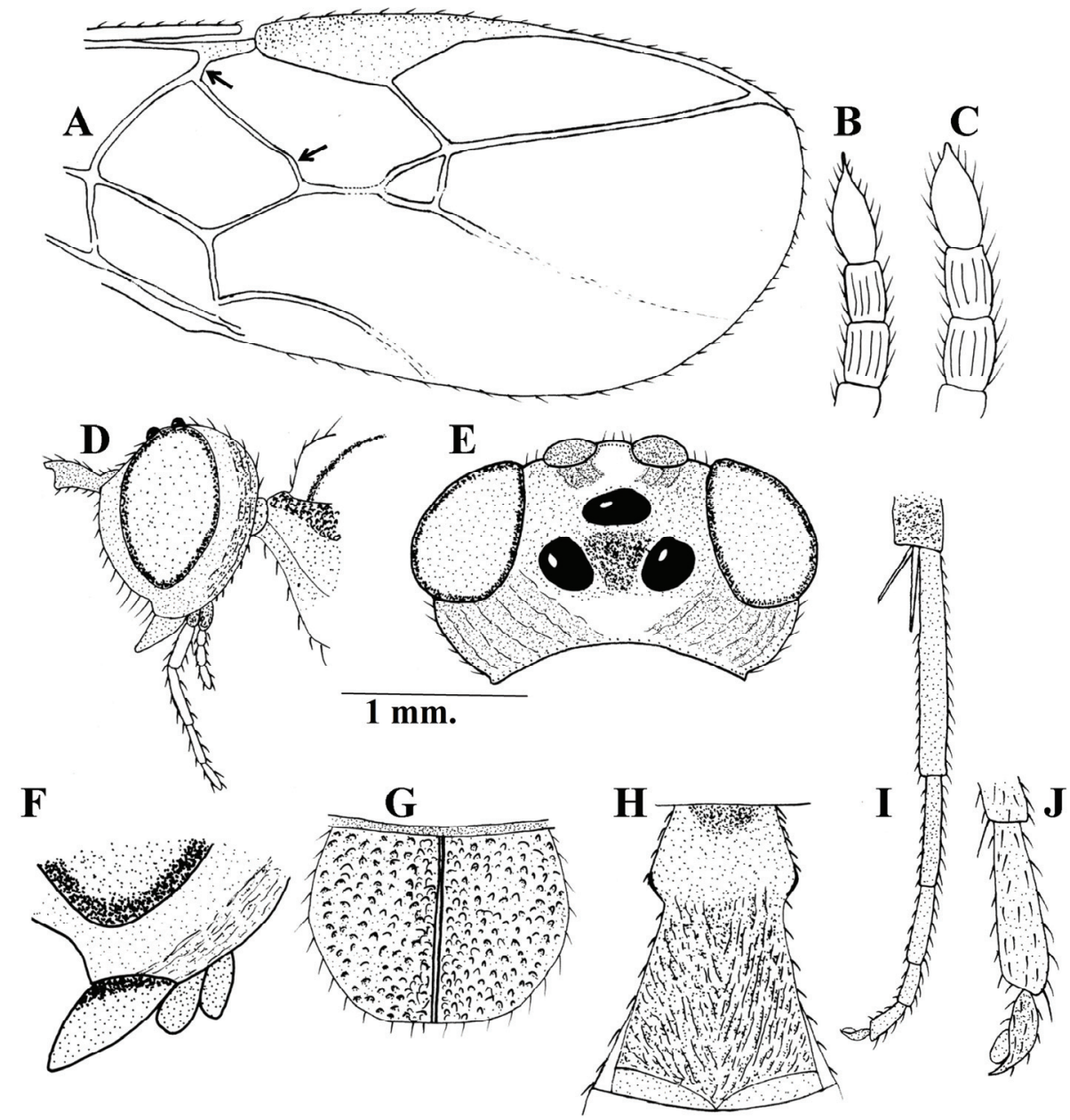

Figure 5. A, B-J, Microtypus aegypticus sp. n. (A) apical half of fore wing $(1 \times$ scale line); (B) apex of antenna $(4.5 \times$ scale line); (D) head, lateral aspect $(0.9 \times$ scale line $)$; (E) head, dorsal aspect $(1.2 \times$ scale line $) ;(F)$ detail of malar space $(3.2 \times$ scale line $) ;(G)$ propodeum $(2 \times$ scale line); (H) first metasomal tergite $(1.8 \times$ scale line); (I) Hind tarsi $(0.9 \times$ scale line $)$; $(\mathrm{J})$ hind claw (4.5 $\times$ scale line); (C) apex of antenna, M. desertorum Shestakov $(4 \times$ scale line).

Microtypus algiricus Szépligeti, 1908 (Figures 1A, 1D, 1G, 2C, 3A, 3D, 4A, 4D)

Microtypus algiricus Szépligeti, 1908: 427, ô.

Microtypus algiricus var. Enderleini Fahringer, 1937: 399.

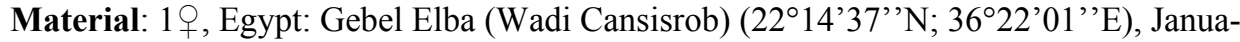
ry 1933 (leg. Priesner), light trap [PPDD]. - 1\%, Egypt: Gebel Elba (W. Eifingab) (2208'39'’N; 3318'00'’E), 7.ii.1933 (leg. Priesner), light trap [PPDD].

Diagnosis (female): Characterised by its enlarged eyes and the anterior ocellus relatively bulging (Figure 1A, D). Body length $6.8 \mathrm{~mm}$; fore wing length $6.2 \mathrm{~mm}$. - Head. Antenna 45-segmented, length of eye in dorsal view 2.5 times temple; OOL: OD: POL 
$=4: 10: 13$; malar space very short, at most 0.1 times basal width of mandible (Figure 1A, D, G), the first segment of maxillary palp distinctly elongated (Figure 1D). Mesosoma. Length of mesosoma 1.7 times its height; generally finely punctate, except for propodeum which is coarsely rugose, smoother postero-laterally, with well-indicated and long areola and a weak short median carina (Figure 3A); anterior half of pronotum laterally with irregular coarse strigulations. - Wings. Fore wing (Figure 2C): vein 1-SR distinct, medium-sized, parallel-sided; veins r: 3-SR+SR1: 2-SR: r-m = 16:56:19:11; vein $1-\mathrm{SR}+\mathrm{M}$ slightly sinuated to nearly straight; SMC2 distinctly petiolate with very short petiole. - Legs. Length of hind tibial spurs 0.3 times and 0.4 times basitarsus (Figure 4A), length of basitarsus 10.8 times its maximum width (Figure 4A), hind claw slender basally (Figure 4D). - Metasoma. T1 1.7 times its apical width, its surface longitudinally costulate, smooth laterally, somewhat constricted behind spiracles (Figure 3D); ovipositor sheath 0.45 times fore wing. - Colouration. Generally brownish-yellow species (but metasoma somewhat darkened), stemmaticum with same colour as vertex, whole antenna (except yellowish ventral side of scapus and pedicellus) dark brown, pterostigma almost yellow (except for light brown ventral border), fore wing membrane hyaline with light brown venation (but slightly darker near veins $\mathrm{r}, 1-\mathrm{M}$ and $\mathrm{C}+\mathrm{SC}+\mathrm{R}$ ), hind femur slightly darker than rest of yellowish legs.

Male. Very similar to female, but with darker mesosoma and coarser sculpture (especially metanotum which with two defined ridges; Szépligeti, 1908); pterostigma faintly infuscate (Čapek \& van Achterberg, 1992). As described by Čapek and van Achterberg (1992) the colour of scapus and pedicellus is slightly contrasting with colour of flagellomeres. However, it differs by having 49 antennal segments and T1 1.6 times its apical width.

Distribution: Algeria, China and Jordan (Yu et al., 2012), Armenia and Iraq (Samin, Achterberg \& Erdoğan, 2016), Egypt (new record).

Host records. Unknown.

Microtypus desertorum Shestakov, 1932 (Figures 1C, 1F, 1H, 2B, 3B, 3E, 4B, 4E, 5C

Microtypus desertorum Shestakov, 1932: 262, 위.

Microtypus mongolicus Fahringer, 1937: 400.

Material: 1, Egypt: Gebel Elba (Wadi Hekwal) (22¹1'56’'N; 36²1'18'’E), 27.i.1933 (leg. Priesner) [PPDD]. - 2ㅇ, Egypt: Gebel Elba (Bir = Wadi? Cansisrob) (22¹4’38'’N; 36²2’09'E), 28.i.1933 (leg. Priesner) (labelled PNG 205) [PPDD]. -

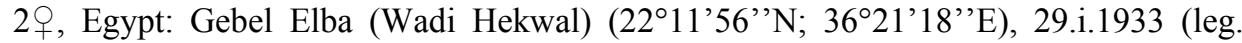

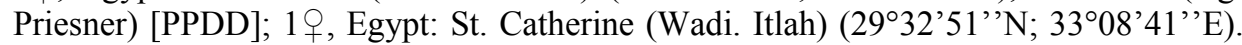

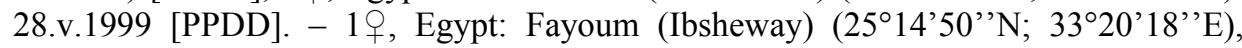
2.iv.2010 [EFC]. - 1 , , Egypt: Bahariya oasis (El Hara) $\left(28^{\circ} 50^{\prime} 09^{\prime}{ }^{\prime} \mathrm{N} ; 8^{\circ} 18^{\prime} 12^{\prime \prime} \mathrm{E}\right)$, 23.vi.2013 (light trap) (leg. Edmardash) [EFC].

Diagnosis (female). Body length 4.9-5.0 mm; fore wing length $4.8 \mathrm{~mm}$. - Head. Antenna 38-segmented; length of eye in dorsal view twice temple (Figure 1C); OOL:OD:POL $=9: 10: 17$ (ocelli are obviously more separated from each other than in any other Egyptian Microtypus spp.) (Figure 1C); malar space 0.2 times (or slightly more) basal width of mandible (Figure $1 \mathrm{~F}, \mathrm{H}$ ). - Mesosoma. Length of mesosoma 1.6 times its height; propodeum moderately rugose but coarser medio-posteriorly, with angulated and smoother areola, with short median carina (Figure 3B). - Wings. Fore wing (Figure 2B) with vein 1-SR distinct, medium-sized; veins r: 3-SR+SR1: 2-SR: r-m $=12: 48: 16: 6$; vein 1-SR+M straight; SMC2 distinctly petiolate. - Legs. Hind tibial 
spurs 0.45 times and 0.5 times as long as hind basitarsus, length of hind basitarsus 9.5 times its maximum width (Figure 4B), hind claw relatively broader basally (Figure 4E). - Metasoma. T1 1.8 times its apical width, its surface densely superficially rugose and hardly constricted behind spiracles (Figure $3 \mathrm{E}$ ); ovipositor sheath 0.5 times fore wing length. - Colouration: Generally dark brown to blackish species, with yellowish legs and pterostigma, parastigma darker, stemmaticum black, metanotum, the apical border of propodeum, T1 laterally and the following two or three (sometimes) metasomal tergites posteriorly blackish.

Male: Similar to female but has antenna 39-43-segmented (Čapek \& van Achterberg, 1992).

Variation. This is one of the most variable Microtypus spp., in some specimens, body is distinctly yellowish (including legs), the wing venation and pterostigma paler; the body with coarser sculpturing especially the face and $\mathrm{T} 1$, the terminal third of antenna black. All specimens examined have length of hind basitarsus 9.5 times its maximum length (in Čapek \& van Achterberg, 1992 hind basitarsus 11-12 times its maximum width; the spine of hind claw is much broader than that of illustrated in Čapek and van Achterberg (1992).

This species and $M$. wesmaelii Ratzeburg are both highly variable species, resulting in overlap of many characters, including colour and body sculpturing:

- Malar space about 0.6 times basal width of mandible; vein $r$ of fore wing (Figure 2A) 0.85 times maximum width of pterostigma, vein 1-SR very small (it appears as if and 1-SR $+\mathrm{M}$ arise directly from pterostigma), angle formed between ventral border of pterostigma and vein $r$ is slightly more than $90^{\circ}$, veins $1-\mathrm{CU} 1$ and CU1b distinct; ovipositor sheath (at least) 0.75 times fore wing length M. wesmaelii Ratzeburg

- Malar space 0.2-0.3 times basal width of mandible (Figure 1F, H); vein $r$ of fore wing (Figure 2B) 0.75 times maximum width of pterostigma, vein 1-SR distinct and medium-sized, angle formed between ventral border of pterostigma and vein $\mathrm{r}$ is slightly less than $90^{\circ}$, veins $1-\mathrm{CU} 1$ and CU1b are indistinct ; ovipositor sheath (at most) 0.56 times fore wing length M. desertorum Shestakov

The venation of fore wing of this species shows two spatial forms, in the Central Asian specimens, vein $1-\mathrm{SR}+\mathrm{M}$ is slightly sinuated and SMC2 sessile, while those of the North African specimens, vein 1-SR+M straight and SMC2 distinctly petiolate (Čapek \& van Achterberg, 1992; Farahani, Talebi, van Achterberg \& Rakhshani, 2014); in our specimens (Figure 2B) collected either from St. Catherine (South Sinai), Fayoum and Bahariya oasis (which all belong to the Western Palaearctic ecozone) and Gebel Elba (Afrotropical ecozone) are in agreement with the North African form.

Distribution: Algeria, China, Iran, Kazakhstan, Mongolia, Turkmenistan and Uzbekistan (Yu et al., 2012), Egypt (new record).

Host records. Unknown

Microtypus vanharteni van Achterberg, 2010 (Figures 1C, 1E, 2D, 3C, 3F, 4C)

Microtypus vanharteni van Achterberg, 2010: 382, ㅇ.

Martial: 1ㅇ, Egypt: Gebel Elba (Wadi Aideb) $\left(22^{\circ} 15^{\prime} 00^{\prime \prime} \mathrm{N} ; 36^{\circ} 25^{\prime} 59^{\prime}\right.$ 'E), January 1939 (leg. Selim) [PPDD]. - 2, Egypt: W. Allaqi (24¹7'00'’N; 3655'01'’E), January 1963 (leg. Shalaby) (det. R. D. Eady as Microtypus sp.), on Anethum [PPDD]. - 1의, 


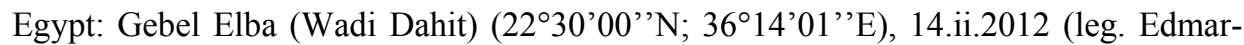
dash) (yellow pans) [EFC].

Diagnosis (female). Body length 6.0-6.1 mm., fore wing length 5.2-5.4 mm. Very similar to UAE specimens but differ in the following: Egyptian specimens has length of eye in dorsal view 2.9 times temple (Figure 1C) (3.2 times in UAE specimens, van Achterberg, 2010), malar space slightly less than 0.3 times basal width of mandible (Figure $1 \mathrm{E}$ ), median carina of propodeum longer than that of holotype (Figure 3C) (van Achterberg, 2010), as well as vein 1-SR+M is distinctly sinuate in Egyptian specimens (Figure 2D); metasoma largely blackish (as in part of the type series) and first metasomal tergite with two defined longitudinal ridges (Figure 3F).

Distribution: UAE (van Achterberg, 2010), Egypt (new record).

Host records: Unknown

\section{Key to the Microtypus species in Egypt}

1 Malar space 0.1-0.3 times basal width of mandible; length of ovipositor sheath 0.45-0.55 times fore wing length; antenna 38-45-segmented; OOL: OD 0.4-1.2; fore wing 4.8-6.2 mm; T1 weakly or hardly constricted behind spiracles (Figure $3 \mathrm{D}-\mathrm{F}$ ) 2

- Malar space 0.6 times basal width of mandible (Figure 5D, F); length of ovipositor sheath 0.34 times fore wing length; antenna 39-40segmented; OOL: OD 0.9-1.3; fore wing length $5.8 \mathrm{~mm}$.; T1 distinctly strongly constricted behind spiracles (Figure $5 \mathrm{H}$ ) Microtypus aegypticus sp. $\mathrm{n}$.

2- Malar space 0.1 times basal width of mandible (Figure 1A, D, G); eyes particularly enlarged and anterior ocellus distinctly bulging (Figure 2A, D); ovipositor sheath 0.45 times fore wing length; antenna 45 segmented Microtypus algiricus Szépligeti

- Malar space 0.2-0.3 times basal width of mandible; eyes and anterior ocellus less enlarged; ovipositor sheath 0.50-0.55 times fore wing length; antenna 38-43-segmented

3 Inner hind tibial spur 0.5 times hind basitarsus length (Figure 4B); hind basitarsus 9.5 times as long as its maximum width (Figure 4B); OOL: OD in female 0.9-1.0; T1 1.8 times its apical width, nearly smooth (Figure 4E); antenna entirely dark brown Microtypus desertorum Shestakov

- Inner hind tibial spur 0.4 times hind basitarsus length (Figure 4C); hind basitarsus 12.1 times its apical width (Figure 4C); OOL: OD 0.5-1.2; T1 1.6 times its apical width, densely superficially rugose (Figure $3 \mathrm{~F}$ ), with 2-3 very slight carinae or elements at base; antenna with scapus and pedicellus distinctly paler than F1 and following segments

Microtypus vanharteni van Achterberg

\section{Disclosure Statement}

No potential conflict of interest was reported by the authors.

\section{References}

Achterberg, C. van (1984): Addition to the revision of the genus Zele Curtis (Hymenoptera: Braconidae). Entomologische Berichten (Amsterdam), 44, 110-112. 
Achterberg, C. van (1987): Revisionary notes on the subfamily Orgilinae (Hymenoptera: Braconidae). Zoologische Verhandelingen Leiden, 242, 1-111.

Achterberg, C. van (1992): Revision of the genera of the subfamily Microtypinae (Hymenoptera: Braconidae). Zoologische Mededelingen Leiden, 66, 369-380.

Achterberg, C. van (1993): Illustrated key to the subfamilies of the Braconidae (Hymenoptera: Ichneumonoidea). Zoologische Verhandelingen Leiden, 283, 1-189.

Achterberg, C. van (1997): Subfamily Aphidiinae. Betylobraconinae. Cenocoelinae. Microtypinae. Orgilinae. In: R. A. Wharton, P. M. Marsh \& M. J. Sharkey, Manual of the New World genera of the family Braconidae (Hymenoptera). No. 1 (pp. 118-131, 136-139, 185-192, $317-$ 320, 367-370, 397-402). International Society of Hymenopterists. Special Publication: Washintgon, D.C.

Achterberg, C. van (2010): Order Hymenoptera, family Braconidae. Genus Microtypus Ratzeburg (Hymenoptera: Braconidae: Microtypinae). Arthropod Fauna of the United Arab Emirates, 3, 381-387.

Al-Gohary, I. H. (2008): Floristic composition of eleven wadis in Gebel Elba, Egypt. International Journal of Agriculture and Biology, 10, 151-160.

Benson, C. W., Clancey, P. A., Frey, C. H., Newman, K., Prigogine, A., \& Snow, D. W. (1979): Afrotropical Region: a substitute name for Sclater's Ethiopian region. Ibis, 121, 518.

Boulos, L. (1999-2005): Flora of Egypt. Vol. 1-4. Cairo: Al Hadara Publishing.

Čapek, M. (1970): A new classification of the Braconidae (Hymenoptera) based on cephalic structure of the final instar larva and biological evidence. Canadian Entomologist, 102, 846875.

Čapek, M., \& Achterberg, C. van (1992): A revision of the genus Microtypus (Hymenoptera: Braconidae). Zoologische Mededelingen Leiden, 66, 323-338.

El-Hadidi, M. N. (2000): Flora Aegyptiaca. Vol. 1. Cairo: The Palm Press and Cairo University Herbarium.

Fahmy, I. R. (1936): Report on Gebel Elba, 7: 1-57. Publishing by the Egyptian University.

Fahringer, J. (1937): Opuscula braconologica. Band 4. Palaearktische Region. Lieferung 4-6 (p. 257-520). Vienna: Fritz Wagner.

Farahani, S., Talebi, A. A., Achterberg C. van, \& Rakhshani, E. (2014): A taxonomic study of Orgilinae and Microtypinae from Iran (Hymenoptera, Braconidae). Spixiana, 37, 93-102

Harris, R. A. (1979): A glossary of surface sculpturing. Occasional Papers in Entomology, 28, 131.

Sabahatullah, M., Inayatullah, M. \& Tahira, Q. A.(2015): First record of Microtypinae (Hymenoptera: Braconidae) from Pakistan with the description of a new species. Journal of Entomology and Zoology Studies, 3, 127-130.

Samin, N., Achterberg, C. van \& Çetin Erdoğan, Ö (2016): A faunistic study on some subfamilies of Braconidae (Hymenoptera: Ichneumonoidea) from Iran. Arquivos Entomolóxicos, 15, 153161.

Sharanowski, B. J., Dowling, A. P. G., \& Sharkey, M. J. (2011): Molecular phylogenetics of Braconidae (Hymenoptera: Ichneumonoidea) based on multiple nuclear genes, and implication for classification. Systematic Entomology, 36, 549-572.

Shestakov, A. (1932): Zur Kenntnis der asiatischen Braconiden. Zoologische Annalen (Würzburg), 99, 255-263.

Springuel, I., \& Sheded, M. (1997): The plant biodiversity of the Wadi Allaqi biosphere reserve (Egypt): impact of Lake Nasser on a desert wadi ecosystem. Biodiversity and Conservation, 6, 1259-1275.

Szépligeti, G. (1908): Braconiden aus der Sammlung des ungarischen National-Museums. 2. Annales Historico-Naturales Musei Nationalis Hungarici, 6, 397-427.

Wharton, R. A. (1997): Introduction. Alysiinae. Gnamptodontinae. Homolobinae. Macrocentrinae. Orgilinae. In: R. A. Wharton, P. M. Marsh \& M. J. Sharkey, Manual of the new world genera of the family Braconidae (Hymenoptera). No.1 (p. 1-18, 257-260, 279-284, 311-316, 379-396). International Society of Hymenopterists, Special Publication: Washington, D.C.

Yu, D. S., Achterberg, C. van, \& Horstmann, K. (2012): World Ichneumonoidea 2005. Taxonomy, biology, morphology and distribution. Interactive electronical catalogue. [DVD/CD-Rom].

Zahran, M. A., \& Willis, A. J. (1992): The vegetation of Egypt. London: Chapman and Hall. 